\title{
HUBUNGAN PENGETAHUAN ORANG TUA TENTANG PENCEGAHAN KARIES GIGI DENGAN INDEKS DMF-T PADA ANAK UMUR 9-11 TAHUN DIKELURAHAN GIRIAN BAWAH LINGKUNGAN VI KECAMATAN GIRIAN KOTA BITUNG
}

\author{
Jeana Lydia Maramis ${ }^{1}$, Vega Roosa Fione ${ }^{2}$ \\ 1,2) Jurusan Keperawatan Gigi Poltekkes Kemenkes ManadoJl.RW.Mongisidi Malalayang II Manado \\ Email : jeanalydiamaramis@gmail.com
}

\begin{abstract}
ABSTRAK
Peran serta orang tua sangat diperlukan didalam membimbing, memberikan pengertian, mengingatkan dan meyediakan fasilitas kepada anak agar anak dapat memelihara kebersihan gigi dan mulutnya. Pengetahuan orang tua sangat penting dalam mendasari terbentuknya perilaku yang mendukung kebersihan gigi dan mulut anak.Penelitian ini bertujuan untuk mengetahui hubungan pengetahuan orang tua tentang pencegahan karies gigi dengan indeks DMF-T pada anak umur 9-11 tahun di Kelurahan Girian Bawah Lingkungan VI Kecamatan Girian Kota Bitung.

Penelitian ini menggunakan metode analitik dengan pendekatan cross sectional study dengan mengukur pengetahuan orang tua dan indeks DMF-T anak yang berlokasi di KelurahanGirianBawahLingkungan VI Kecamatan Girian Kota Bitung. Sampel yang digunakan yaitu 39 anak 9-11 tahun beserta orang tua. Data yang diperoleh ditabulasi dan diuji menggunakan correlation kendall tau untuk melihat hubungan pengetahuan orang tua tentang pencegahan karies gigi dengan indeks DMF-T.

Hasil analisis menggunakan uji correlation kendall tau didapatkan nilairsebesar 0,509 dengan kekuatan korelasi sangat rendah dengan nilai $p$ sebesar 0,001 lebih kecil dari 0,05 sehingga terdapat nilai korelasi yang bermakna antara variabel pengetahuan pencegahan karies gigi dengan variabel indeks DMF-T anak dengan arah korelasi negatif (-) yang berarti semakin besar nilai pengetahuan pencegahan karies gigi maka semakin kecil nilai indeks DMF-T. Sehingga disimpulkan bahwa ada hubungan antara variabel bebas dengan variabel terikat.
\end{abstract}

\section{Kata kunci : Pengetahuan, Pencegahan Karies Gigi, Indeks DMF-T}

\begin{abstract}
ABSTRAC
The participation of parents is very necessary in guiding, providing understanding, reminding and providing facilities to children so that children can maintain the cleanliness of their teeth and mouth. Parent's knowledge is very important in underlying the formation of behaviors that support children's oral and dental hygiene. This study aims to determine the relationship of parents' knowledge about the prevention of dental caries with DMF-T index in 9-11 year olds in Girian Bawah Lingkungan VI District, Girian Kota District. Bitung.

This study used an analytical method with a cross sectional study approach to measure parental knowledge and the DMF-T index of children located in Kelurahan Girian Bawah Lingkungan VI, Girian District, Bitung City. The sample used is 39 children 9-11 years and parents. The data obtained were tabulated and tested using correlation kendall tau to see the relationship of parents' knowledge about the prevention of dental caries with the DMF-T index.
\end{abstract}


The results of the analysis using the kendall tau correlation test obtained the value of 0,509 with a very low correlation strength with a $p$ value of 0,001 smaller than 0,05 so that there is a significant correlation between the variables of dental caries prevention knowledge with the DMF-T index variable of children with the direction of negative correlation (-) which means that the greater the value of knowledge of prevention of dental caries, the smaller the DMF-T index value. So it is concluded that there is a relationship between the independent variable and the dependent variable.

\section{Keywords: Knowledge, Dental Caries Prevention, DMF-T Index}

\section{PENDAHULUAN}

Pengetahuan seseorang didapat dari adanya stimulus yang ditangkap oleh pancaindera. Pengetahuan bisa diperoleh secara alami maupun secara terencana yaitu melalui proses pendidikan. Pengetahuan akan kesehatan, khususnya kesehatan gigi dan mulut merupakan ranah yang sangat penting untuk terbentuknya tindakan. ${ }^{1}$

Pengetahuan orang tua sangat penting dalam mendasari terbentuknya perilaku yang mendukung atau tidak mendukung kebersihan gigi dan mulut anak ${ }^{2}$. Gigi adalah jaringan tubuh yang paling keras dibandingkan dengan yang lainnya. Namun demikian, gigi merupakan jaringan tubuh yang mudah sekali mengalami kerusakan, ini terjadi ketika gigi tidak memperoleh perawatan semestinya. ${ }^{3}$

Kesehatan mulut penting bagi kesehatan dan kesejahteraan tubuh secara umum dan sangat mempengaruhi kualitas kehidupan termasuk fungsi bicara, pengunyahan, dan rasa percaya diri. Gangguan kesehatan mulut akan berdampak pada kinerja seseorang. Banyak cara untuk dapat mengurangi dan mencegah penyakit gigi dan mulut dengan berbagai pendekatan yang meliputi pencegahan yang dimulai pada masyarakat, perawatan oleh diri sendiri dan perawatan oleh tenaga profesional. $^{4}$
Penyakit pada gigi disebut karies. Karies merupakan suatu penyakit jaringan keras gigi, yaitu email, dentil dan sampai ke jaringan pulpa, yang disebabkan oleh aktivitas suatu jasad renik dalam suatu karbohidrat yang dapat diragikan. ${ }^{5}$ Diperkirakan bahwa 90\% dari anak-anak usia sekolah di seluruh dunia dan sebagian besar orang dewasa pernah menderita karies. Prevalensi karies tertinggi terdapat di Negara Asia dan Amerika Latin. ${ }^{6}$

Penyebab terjadinya karies gigi antara lain :

a. Makanan

Makanan yang lunak dan melekat pada gigi dapat merusak gigi, seperti coklat, biskuit dan lain sebagainya. ${ }^{7}$

b. Waktu

Adanya kemampuan saliva untuk mendepositkan kembali mineral selama berlangsungnya proses karies, menandakan bahwa proses karies tersebut terdiri atas proses perusakan dan perbaikan yang silih berganti. Oleh karena itu, bila saliva ada di dalam lingkungan gigi, maka karies tidak menghancurkan gigi dalam hitungan hari atau minggu, melainkan dalam bulan dan tahun, dengan demikian sebenarnya terdapat kesempatan yang baik untuk menghentikan penyakit ini. ${ }^{5}$

c. Saliva

Kurangnya saliva meningkatkan resiko karies. Fungsi saliva yang 
adekuat penting dalam pertahanan melawan serangan karies, mekanisme perlindungan saliva yaitu aksi pembersihan bakteri, aksi buffer, anti mikroba dan remineralisasi. ${ }^{4}$

d. Plak

Plak gigi merupakan deposit lunak yang melekat erat pada permukaan gigi, terdiri dari mikroorganisme yang berkembang biak dalam suatu matriks intraseluler jika seseorang melalaikan kebersihan gigi dan mulutnya. Plak memegang peran penting dalam terjadinya penyakit gigi dan mulut. Bakteri yang terdapat dalam plak bertanggung jawab pada terjadinya kerusakan gigi, karena bakteri-bakteri tersebut akan melakukan metabolism terhadap sisa-sisa makanan yang tertinggal. ${ }^{4}$

Proses terjadinya karies gigi disebabkan oleh faktor host (penjamu), agent (mikroflora) dan environment (substrat) dan didukung oleh faktor keempat yaitu faktor waktu. Proses terjadinya karies akan terjadi bila keempat faktor yang telah disebutkan di atas akan saling bekerja sama dan masing-masingnya memenuhi kondisi yang sesuai, seperti penjamu yang bersifat rentan, mikroflora yang bersifat kariogenik, substrat yang sesuai dan jangka waktu yang cukup memadai untuk terjadinya proses perubahan pada keempat faktor tersebut. Proses ini dimulai dengan kerusakan jaringan email yang menjadi lunak dan pada akhirnya menyebabkan terjadinya kavitas. Telah banyak dilakukan penelitian oleh para ahli tentang teori penyebab terjadinya karies gigi, namun sampai saat ini masih dianut empat faktor yang mempengaruhinya. ${ }^{8}$

Pencegahan karies gigi dapat dilakukan dengan berbagai cara yaitu:

a. Memelihara kebersihan gigi dan mulut (menghilangkan plak dan bakteri) b. Memperkuat gigi dengan larutan fluor

c. Mengurangi konsumsi makanan yang terlalu manis dan lengket

d. Menyikat gigi sesudah makan dan sebelum tidur malam

e. Menggunakan sikat gigi yang berbulu halus

f. Mengkonsumsi buah-buahan yang berserat dan yang mengandung air sebagai pencuci mulut

g. Periksakan gigi ke dokter gigi setiap enam bulan sekali. ${ }^{9}$

Untuk mengukur pengalaman karies gigi biasanya digunakan indeks pengalaman karies, yaitu DMF-T (untuk gigi tetap) dan def-t (untuk gigi sulung), karena indeks ini yang paling banyak digunakan dan diterima secara universal.

Rumus yang digunakan untuk menghitung DMF-T menurut $\mathrm{WHO}^{10}$ yaitu :

$\mathrm{DMF}-\mathrm{T}=\frac{\mathrm{D}+\mathrm{M}+\mathrm{F}}{\text { Jumlah responden yang diperiksa }}$

Tabel 1. Kriteria DMF-T

\begin{tabular}{ll}
\hline Skor & Keterangan \\
\hline$<1,2$ & Sangat Rendah \\
$1,2-2,6$ & Rendah \\
$2,7-4,4$ & Sedang \\
$4,5-6,5$ & Tinggi \\
$>6,5$ & Sangat Tinggi \\
\hline
\end{tabular}

\section{METODE}

Jenis penelitian yang digunakan yaitu metode analitik dengan pendekatan cross sectional study. Yang menjadi responden dalam penelitian ini yaitu 39 orang tua yang tinggal di Kelurahan Girian Bawah Lingkungan VI Kecamatan Girian Kota 
Bitung untuk diberikan kuesioner yang berisikan 10 pertanyaan dan anak dari orang tua tersebut yang berjumlah 39 orang juga yang berumur 9-11 tahun untuk diperiksa jumlah DMF-Tnya. Penelitian ini dilakukan pada bulan Juli 2018, dan data dianalisa menggunakan uji statistik Paired Sample t Test.

\section{HASIL}

1. Distribusi responden orang tua menurut umur dapat dilihat pada Tabel 2 berikut ini :

Tabel 2. Distribusi Responden Orang Tua Menurut Umur

\begin{tabular}{ccc}
\hline Umur & $\mathrm{N}$ & $\%$ \\
\hline $27-31$ Tahun & 7 & 17,9 \\
$32-$ 36 Tahun & 15 & 38,4 \\
$37-41$ Tahun & 10 & 25,6 \\
42 - 46 Tahun & 7 & 17,9 \\
\hline Total & 39 & 100 \\
\hline
\end{tabular}

Tabel 2 di atas menunjukkan jumlah responden terbanyak pada golongan umur 31-36 tahun (38,4\%), kemudian disusul responden yang berumur 37-41 tahun sebanyak $25,6 \%$, kemudian responden berumur 27-31 tahun dan yang berumur 42-46 tahun sebanyak $17,9 \%$.

2. Distribusi responden orang tua menurut tingkat pendidikan dapat dilihat pada Tabel 3 di bawah ini :

Tabel 3. Distribusi Responden Orang Tua Menurut Tingkat Pendidikan

\begin{tabular}{lll}
\hline Pendidikan & $\mathrm{N}$ & $\%$ \\
\hline S1 & 15 & 38,4 \\
SMA & 12 & 30,7 \\
SMP & 7 & 17,9 \\
SD & 5 & 12,8 \\
\hline Total & 39 & 100 \\
\hline
\end{tabular}

Pada Tabel 3 di atas menunjukkan bahwa responden terbanyak berada pada tingkat pendidikan S1 (38,4\%), kemudian SMA sebanyak 30,7\%, SMP sebanyak $17,9 \%$ dan yang paling sedikit pada tingkat pendidikan SD sebanyak 12,8\%.

3. Distribusi responden orang tua menurut pekerjaan dapat dilihat pada Tabel 4 berikut ini :

Tabel 4. Distribusi Responden Orang Tua Menurut Pekerjaan

\begin{tabular}{ccc}
\hline Pekerjaan & $\mathrm{n}$ & $\%$ \\
\hline PNS & 3 & 7,6 \\
Swasta & 6 & 15,3 \\
IRT & 18 & 46,1 \\
Sopir & 2 & 5,1 \\
Nelayan & 10 & 25,6 \\
\hline Total & 39 & 100 \\
\hline
\end{tabular}

Pada Tabel 4 di atas menunjukkan bahwa jumlah respon yang paling banyak berrada pada pekerjaan sebagai IRT (46,1\%), untuk nelayan sebanyak $25,6 \%$, untuk swasta sebanyak 15,3\%, untuk PNS sebanyak $7,6 \%$ dan yang bekerja sebagai sopir sebanyak $5,1 \%$.

4. Distribusi pengetahuan orang tua tentang pencegahan karies gigi pada anak dapat dilihat pada Tabel 5 di bawah ini :

Tabel 5. Distribusi Pengetahuan Orang Tua Tentang PencegahanKaries Gigi Pada Anak

\begin{tabular}{|c|c|c|}
\hline pengertahuan & $\mathrm{N}$ & $\%$ \\
\hline Baik & 30 & 76,9 \\
\hline Kurang baik & 9 & 23 \\
\hline Total & 39 & 100 \\
\hline
\end{tabular}


Tabel 5 di atas menunjukkan bahwa sebagian besar pengetahuan orang tua tentang pencegahan karies gigi pada anak berada pada kriteria baik $(76,9 \%)$ dan pengetahuan kurang baik sebanyak $23 \%$.
5. Distribusi responden anak menurut umur dan DMF-T dapat dilihat pada Tabel 6 berikut ini:

Tabel 6. Distribusi Responden Anak Menurut Umur \& DMF-T

\begin{tabular}{|c|c|c|c|c|c|c|c|c|c|c|c|c|}
\hline \multirow{3}{*}{$\begin{array}{l}\text { Umur } \\
\text { (Tahun) }\end{array}$} & \multicolumn{8}{|c|}{ Kategori DMF-T } & & & \multicolumn{2}{|c|}{ Total } \\
\hline & \multicolumn{2}{|c|}{$\begin{array}{l}\text { Sangat } \\
\text { Rendah }\end{array}$} & \multicolumn{2}{|c|}{ Rendah } & \multicolumn{2}{|c|}{ Sedang } & \multicolumn{2}{|c|}{ Tinggi } & \multicolumn{2}{|c|}{$\begin{array}{l}\text { Sangat } \\
\text { Tinggi }\end{array}$} & & \\
\hline & $\mathrm{N}$ & $\%$ & $\mathrm{~N}$ & $\%$ & $\mathrm{n}$ & $\%$ & $\mathrm{~N}$ & $\%$ & $\mathrm{n}$ & $\%$ & $\mathrm{~N}$ & $\%$ \\
\hline 9 & 9 & 23 & 1 & 2,5 & 0 & 0 & 0 & 0 & 0 & 0 & 10 & 25,6 \\
\hline 10 & 2 & 5,1 & 9 & 23 & 1 & 2,5 & 0 & 0 & 0 & 0 & 12 & 30,7 \\
\hline 11 & 2 & 5,1 & 11 & 28,2 & 4 & 10,2 & 0 & 0 & 0 & 0 & 17 & 43,5 \\
\hline Total & 13 & 33,3 & 21 & $\begin{array}{l}53,8 \\
\end{array}$ & 5 & 12,8 & 0 & 0 & 0 & 0 & 39 & 100 \\
\hline
\end{tabular}

Pada Tabel 6 di atas menunjukkan bahwa DMF-T dengan kategori sangat rendah terbanyak berada pada anak berumur 9 tahun (23\%) dan DMF-T dengan kategori sedang berada pada anak berumur 11 tahun $(10,2 \%)$. Untuk kategori sangant tinggi dan tinggi tidak ada baik pada anak umur 9 tahun, 10 tahun maupun 11 tahun.

Tabel 7. Distribusi Pengetahuan Orang Tua Dengan Indeks DMF-T Anak

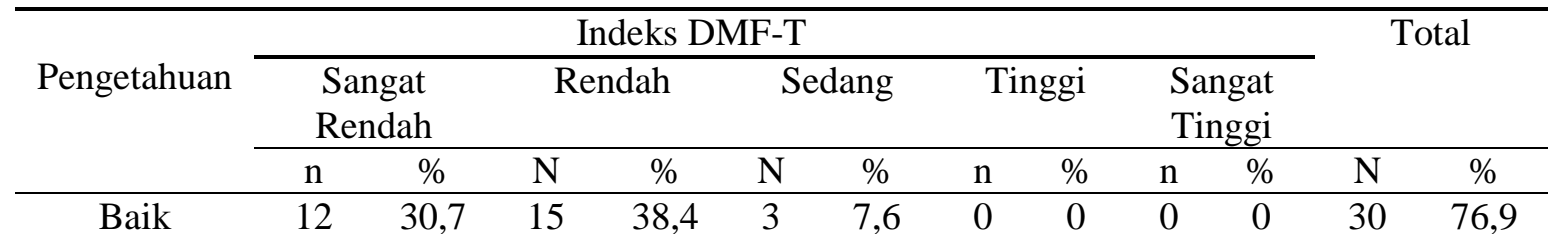

\begin{tabular}{ccccccccccccc} 
Kurang Baik & - & - & 4 & 10,2 & 5 & 12,8 & 0 & 0 & 0 & 0 & 9 & 23 \\
\hline Total & 12 & 30,7 & 19 & 48,7 & 8 & 20,5 & 0 & 0 & 0 & 0 & 39 & 100
\end{tabular}

Pada Tabel 7 di atas menunjukkan bahwa sebagian besar pengetahuan orang tua tentang pencegahan karies gigi pada anak berada pada kriteria baik dan indeks DMF-T dari anak berada pada kategori rendah $(38,4 \%)$, kriteria pengetahuan baik
6. Distribusi pengetahuan orang tua dengan indeks DMF-T anak dapat dilihat pada Tabel 7 di bawah ini : 
dengan indeks DMF-T sedang sebanyak $12,8 \%$.

6. Analisis data menggunakan uji correlation kendall tau dapat dilihat pada Tabel 8 berikut ini :

Tabel 8. Analisis Data Menggunakan Uji Correlation Kendall Tau

\begin{tabular}{|c|c|c|}
\hline \multirow{4}{*}{$\begin{array}{c}\text { Skor } \\
\text { Pengetahuan }\end{array}$} & & $\begin{array}{c}\text { Skor Indeks } \\
\text { DMF-T }\end{array}$ \\
\hline & $\mathrm{R}$ & $-0,509$ \\
\hline & $p$ & 0,001 \\
\hline & $\mathrm{N}$ & 39 \\
\hline
\end{tabular}

Hasil analisis menggunakan uji correlation kendall tau didapatkan nilai sebesar -0,509 dengan kekuatan korelasi cukup kuat yaitu antara nilai 0,40-0,599 dengan nilai $p$ sebesar 0,001 lebih kecil dari 0,05 sehingga dapat dikatakan bahwa hubungan yang bermakna atau signifikan antara variabel pengetahuan pencegahan karies gigi dengan variabel indeks DMF-T, dengan arah korelasi negatif (-) yang berarti semakin besar nilai pengetahuan pencegahan karies gigi maka semakin kecil nilai indeks DMF-T.

\section{PEMBAHASAN}

Pengetahuan merupakan hasil dari tahu, dan ini terjadi setelah orang melakukan pengindraan terhadap suatu objek tertentu. Penginderaan dapat melalui pencaindra manusia, yakni indera pengelihatan, pendengaran, penciuman, rasa, dan raba. Sebagian besar pengetahuan manusia diperoleh melalui penglihatan dan pendengaran. $^{11}$
Sebuah pembentukan keluarga sangat penting peran serta orang tua di dalam membimbing, memberikan pengertian, mengingatkan dan meyediakan fasilitas kepada anak agar anak dapat memelihara kesehatan khususnya kebersihan gigi dan mulutnya. Pengetahuan orang tua sangat penting dalam mendasari terbentuknya perilaku yang mendukung kebersihan gigi dan mulut anak. ${ }^{2}$

Notoatmodjo (2010) menjelaskan bahwa penyebab timbulnya masalah kesehatan gigi dan mulut pada masyarakat dipengaruhi oleh beberapa faktor diantaranya faktor sikap dan tindakan, walaupan masyarakat memiliki pengetahuan yang tinggi tentang pencegahan karies gigi namun tidak diikuti dengan praktek maka keadaan kesehatasn gigi dan mulut tetap jelek. ${ }^{12}$

Melalui penelitian ini dilakukan pengujian untuk mengetahui seberapa kuatnya hubungan pengetahuan pencegahan karies gigi dengan indeks DMF-T pada anak. Untuk aspek pengetahuan tentang pencegahan karies gigi, penyebab karies gig dan akibat karies gigi yang dinilai pada tingkatan tahu (know) dan memahami (comprehension) dan selanjutnya dikorelasikan dengan indeks DMF-T.

Pada distribusi renponden orang tua menurut umur, pekerjaan dan tingkat pendidikan sangat berpengaruh pada tingkat pengetahuan seseorang. Makin tinggi tingkat pendidikan dan lingkungan pekerjaan seseorang dapat membentuk daya pikir ke arah yang lebih baik, sehingga pengetahuan khususnya tentang pencegahan karies gigi pada anak lebih banyak berada pada kategori baik.

Pada distribusi responden menurut pengetahuan orang tua tentang pencegahan karies gigi pada anak berdasarkan 
pekerjaan pada (Tabel 4) menunjukkan bahwa pekerjaan orang tua sebagai ibu rumah tangga memiliki pengetahuan baik yang lebih banyak dibandingkan dengan orang tua yang bekeja sebagai PNS dan wiraswasta memiliki pengetahuan yang kurang baik. Dalam hal ini orang tua yang berada di rumah memiliki banyak waktu bersama anaknya, jadi orang tua dapat mengontrol kesehatan gigi dan mulut anaknya dibandingkan dengan orang tua yang bekerja di luar rumah yang kurang memiliki waktu bersama dengan anaknya.

Menurut Sariningrum (2009), orang tua perlu mengetahui, mengajarkan hal-hal yang baik pada anak, serta melatih anak sejak dini untuk merawat gigi sendiri. Sebaliknya bila orang tua memiliki pengetahuan yang rendah mengenai pencegahan karies, cenderung kurang memperdulikan kesehatan gigi dan mulut anak sehingga dapat menyebabkan terjadinya karies gigi ${ }^{13}$. Hal ini sejalan dengan penelitian Hamadi, dkk (2015) di Kelurahan Mendono Kecamatan Kintom Kabupaten Banggai menunjukkan bahwa sebagian besar responden adalah ibu dengan pengetahuan baik, sehingga pembentukan karies gigi dapat dicegah. ${ }^{14}$

Distribusi pengetahuan orang tua dengan indeks DMF-T pada anak (Tabel 7), menunjukkan bahwa hubungan pengetahuan orang tuan tentang pencegahan karies gigi dengan indeks DMF-T pada anak sebagian besar terdapat pada kategori pengetahuan baik dengan status indeks DMF-T rendah yaitu 38,4\%, sedangkan kriteria pengetahuan baik dengan status indeks DMF-T sedang sebanyak $7,6 \%$. Pengetahuan orang tua yang diperoleh baik dari tenaga kesehatan gigi maupun dari media sosial belum merubah pola pikir dan perilaku dalam memelihara kesehatan gigi dan mulut anak sehingga indeks DMF-T anak lebih banyak berada pada kategori rendah. Sedangkan pengetahuan baik dengan indeks DMF-T sangat rendah hanya $30,7 \%$ dan pada penelitian ini juga masih didapatkan orang tua dengan pengetahuannya kurang baik namun indeks DMF-T rendah yaitu sebanyak $10,2 \%$, dan kriteria pengetahuan kurang baik dengan indeks DMF-T sedang ada1 2,8\%. Dari hasil penelitian ini persentase pengetahuan baik dengan indeks DMF-T sangat rendah masih kurang dan masih didapatkan orang tua yang memiliki pengetahuan kurang baik sehingga masih dibutuhkan pendidikan tentang kesehatan gigi dan mulut khususnya tentang pencegahan karies gigi pada anak agar kebersihan gigi dan mulut dari anak dapat ditingkatkan, sehingga orang tua mampu membimbingan anaknya untuk memelihara kebersihan gigi dan mulut agar anak dapat mengubah pola pikir dan dapat berperilaku lebih baik lagi untuk menjaga kebersihan gigi dan mulut. ${ }^{1}$

Hasil uji statistik yang menggunakan uji correlation kendall tau antara pengetahuan orang tua tentang pencegahan karies gigi dengan indeks DMF-T anak diperoleh nilai korelasi sebesar -0,509 berada diantara nilai 0,40-0,599 yaitu korelasi sedang dengan arah korelasi negatif (-), dengan nilai signifikan sebesar $0,001<0,05$ yang berarti hipotesis nol $\left(\mathrm{H}_{0)}\right.$ tidak diterima dan hipotesis alternatf $\left(\mathrm{H}_{1}\right)$ diterima dengan pernyataan bahwa pengetahuan orang tua tentang pencegahan karies gigi ada hubungan dengan indeks DMF-T pada anak dengan arah korelasi negatif (-) dimana semakin tinggi pengetahuan maka indeks DMF-T semakin rendah, dengan kata lain semakin tinggi pengetahuan maka indeks DMF-T semakin baik pula. 


\section{KESIMPULAN}

Berdasarkan penelitian yang telah dilakukan di Kelurahan Girian Bawah Lingkungan VI Kecamatan Girian Kota Bitung diperoleh hasil analisis menggunakan uji correlation kendall tau didapatkan bahwa ada hubungan yang signifikan antara pengetahuan orang tentang pencegahan karies gigi dengan indeks DMF-T pada anak umur 9-11 tahun di Kelurahan Girian Bawah Lingkungan VI Kecamatan Girian Kota Bitung.

\section{SARAN}

1. Kepada orang tua agar menambah pengetahuan tentang pencegahan karies gigi dengan membaca informasi--informasi kesehatan gigi dan mulut yang ada di media cetak maupun media elektronik

2. Kepada orang tua yang memiliki anak dengan indeks DMF-T yang masih tinggi agar lebih memperhatikan dan rajin mengingatkan kepada anaknya agar dapat memelihara kesehatan gigi dan mulut dan segera pergi memeriksaan gigi anaknya ke puskesmas atau ke dokter gigi terdekat untuk dilakukan perawatan.

3. Kepada anak-anak agar dapat menjaga kesehatan gigi dan mulut dengan cara menyikat gigi $2 \mathrm{x}$ sehari pagi setelah sarapan dan malam sebelum tidur, mengurangi makan makanan yang manis dan melekat serta dapat mengunjungi puskesmas atau dokter gigi minimal 6 bulan sekali atau 1 tahun 2 kali.

\section{DAFTAR PUSTAKA}

1. Budiharto, (2013). Ilmu Perilaku Kesehatan dan Pendidikan Kesehatan Gigi, EGC. Jakarta.

2. Margareta, S. (2012). Terapi Alami Gigi Agar Putih dan Sehat. Pustaka Cerdas. Yogyakarta.

3. Hermawan, (2010).Menyehatkan Daerah Mulut. Buku Biru. Jogjakarta.

4. Putri,H.M., Herijulianti, E., dan Nurjannah, N. (2010). Ilmu Pencegahan Penyakit Jaringan Kerasdan Jaringan Pendukung Gigi. EGC. Jakarta

5. Kidd, E.A.M., and Bechal, S.J. (1992). Dasar-Dasar Karies Penyakit dan Penanggulangannya.EGC. Jakarta.

6. Irma, I.Z., dan Intan., S.A. (2013). Penyakit, Gigi, Mulut Dan THT. Nuha Medika. Yogyakarta.

7. Tarigan R. (2015). Karies Gigi. EGC. Jakarta.

8. Bahar, (2011) .Paradigma Baru Pencegahan Karies Gigi. Fakultas Ekonomi. Universitas Indonesia. Jakarta.

9. Sriyono,N.W. (2005). Pengantar Ilmu Kedokteran Gigi Pencegahan. Medika Fakultas Kedokteran UGM. Yogyakarta.

10. World Health Organization, (2013). Oral Health Surveys Basic Methods. Fifth Edition Karies Gigi Anak. Jurnal Dentiono. 2(1:56-60). Diakses pada 8 Juli 2018.

11. Notoatmodjo, S. (2007). Promosi Kesehatan \& Ilmu Perilaku. Rineka Cipta. Jakarta

12. Notoatmodjo, S. (2010). Metodologi Penelitian Kesehatan. Rineka Cipta. Jakarta. 
13. Sariningrum, E. (2009). Hubungan Tingkat Pendidikan, Sikap dan Pengetahuan Orang Tua Tentang Kebersihan Gigi dan Mulut Pada Anak Balita 3-5 Tahun dengan Tingkat Kejadian Karies di PAUD Jatipurno. Berita Ilmu Keperawatan. 2 (3:121-123). Diakses pada tanggal 10 Juli 2018.

14. Hamadi,D.A., Gunawan.P.N., dan Mariati, N.W. (2015). Gambaran Pengetahuan Orang Tua Tentang Pencegahan Karies dan Status Karies Murid SD Kelurahan Mendono Kecamatan Kintom Kabupaten Banggai. Jurnal e-GiGi. 3 (1:9-11). Diakses pada tanggal 10 Juli 2018. 